\title{
62- The anatomy of two politically divided nations in the 1970s: Northern Ireland in Milkman and Turkey in Gece Dersleri
}

Alper TULGAR ${ }^{1}$

APA: Tulgar, A. (2021). The anatomy of two politically divided nations in the 1970s: Northern Ireland in Milkman and Turkey in Gece Dersleri. RumeliDE Dil ve Edebiyat Araştırmaları Dergisi, (25), 1030-1044. DOI: 10.29000/rumelide.1032573.

\begin{abstract}
Milkman written by Anna Burns depicts a politically violent period in the history of Northern Ireland called the "Troubles". The religious and political contrasts between Catholic Irish Republicans, who aimed to form a free Northern Ireland by getting out of the domination of England and Protestant British Loyalists who aimed to stay united, constantly piled up and led to cruel acts. Paramilitaries from both sides terrorized the country with thousands of deaths. Anna Burns depicts the period with first-person narrator, an eighteen-year-old young girl whose only purpose is to read novels from previous centuries. Gece Dersleri by Latife Tekin portrays a militia named Gülfidan with the alias Secretary Wind. Gülfidan recollects her past with guilt and shame. Turkey in the 1970s went through unprecedented protests and strikes that led to the coup in 1980. As part of a leftist organization, Gülfidan takes the responsibility of the political chaos in Turkey.
\end{abstract}

Keywords: Anna Burns, Milkman, The Troubles, Northern Ireland, Latife Tekin, Gece Dersleri

\section{0'lerde politik açıdan bölünmüiş iki ulusun anatomisi: Milkman romanında Kuzey İrlanda ve Gece Dersleri romanında Türkiye}

\section{$\ddot{\mathbf{O} z}$}

\begin{abstract}
Anna Burns'ün Milkman romanı, "Sorunlar” olarak bilinen Kuzey İrlanda tarihindeki politik açıdan vahşet dolu bir dönemi kaleme alır. İngiltere hegemonyasından çıkarak özgür bir Kuzey İrlanda oluşturmayı amaçlayan Katolik İrlanda Cumhuriyetçileri ve İngiltere ile birlikte kalmayı amaçlayan İngiliz birlik yanlısı Protestanlar arasındaki dini ve politik zıtlıklar sürekli birikerek vahşi eylemlere neden olur. İki taraftan da paramiliter birlikler ülkeyi terörize eder ve binlerce ölüm kaydedilir. Anna Burns dönemi tek amacı önceki dönem romanlarını okumak olan on sekiz yaşındaki genç bir kızın gözünden birinci şahıs anlatısı ile aktarır. Latife Tekin’in Gece Dersleri Sekreter Rüzgâr kod anıyla anılan Gülfidan isimli militanı anlatır. Gülfidan geçmişi suçluluk ve utançla hatırlar. 1970’lerde Türkiye, 1980 darbesine yol açan benzeri görülmemiş protesto ve grevler yaşamıştır. Solcu bir örgüte üye olan Gülfidan Türkiye'deki politik kaosun sorumluluğunu üstlenir.
\end{abstract}

Anahtar kelimeler: Anna Burns, Milkman, Sorunlar, Kuzey İrlanda, Latife Tekin, Gece Dersleri

Dr. Öğr. Gör., Atatürk Üniversitesi, Yabancı Diller Yüksekokulu, Yabancı Diller Bölümü (Erzurum, Türkiye), alper.tulgar@atauni.edu.tr, ORCID ID: oooo-0o02-8784-0795 [Araştırma makalesi, Makale kayıt tarihi: 18.10.2021kabul tarihi: 20.12.2021; DOI: 10.29000/rumelide.1032573] 


\section{Introduction}

Gece Dersleri (Night Classes) is a novel written by Latife Tekin in 1986 after the 1980 Turkish coup d'état. Tekin uses fragmented pieces of paragraphs while forming her novel and uses a poetic language. Like middle sister in Milkman, the narrator named Gülfidan (also known as Secretary Wind) is an eighteen-year-old young woman who participates in a leftist organization. The novel uses a nonlinear and disjointed narrative which is difficult to follow. Gülfidan, as a part of leftist group, struggles to find her true identity. Middle sister in Milkman and Gülfidan in Gece Dersleri have complete contrasted ideologies. Middle sister does not want to participate in any forms of political activities while Gülfidan is torn apart between her involvement with paramilitaries and her individualism. She cannot grasp the facticity of her personality since she believes in the righteousness of her cause more than her identity. She has to face the fact that in the past she served as a militant. Middle sister, on the other hand, struggles to keep herself away from the political turmoil of the era. She, as an individual, does not show interest to be a part of paramilitary groups.

A comparison is drawn between the two novels in terms of questioning the true nature of womanhood. Three women, Gülfidan, her alter ego Secretary Wind, and middle sister show striking parallels that reveal the challenges women have to suffer during the 1970s, when the two countries Northern Ireland and Turkey went through traumatic times. The two countries were politicized and polarized more than ever, and politics became an inseparable part of people's daily lives. It should be stated that the polarization in Turkey partly emerged from differences in religion as well like it did in Northern Ireland. People with extreme right views defined themselves as religious while people from the left-wing had more liberal views. People identified themselves with parties, which led to a severe collectivism. The reason Gülfidan slowly loses her individuality and turns into Secretary Wind, a form of Kafkaesque metamorphosis, is strengthened with the contradictory aims of two main political parties.

Milkman, the Booker winner, by Anna Burns set in 1970s portrays a young witty woman surrounded by slanders. In a society where women are treated with condescension, a young woman can be easily dishonoured by men. In a politically torn apart country full of violence and deaths, female body once again is questioned and scrutinized. This study is a selective reading of Milkman to investigate the representation of female body and gender apartheid.

The narrator, without a name, is eighteen-year-old and rumoured to have an affair with an older man, 41, called Milkman. He is defined by the narrator as a renouncer of the state. $\mathrm{He}$ is in the Catholic/nationalist minority, a renouncer of the state and at war with pro-government groups. Throughout the novel, the characters' names are not given, and they are referred by the use of adjectives or mainly their relation to the narrator. The narrator is frequently called middle sister. At a time when people, being photographed by government agents at parks behind bushes, are labelled as the defenders of anti-establishment ideology, being free and being a woman simultaneously require defiance.

In an anti-democratic state, people are ineluctably surveilled and manipulated. The first brother-in-law, the narrator's eldest sister's husband, makes inappropriate sexual comments and verbally abuses the narrator since the age of twelve. Although he does not resort to violence, he is depicted as a dangerous man that can spread false gossips about people. However, the milkman, the narrator's stalker, is depicted as more dangerous. People in the society spread gossips so as to harm people outside their territorial rules and lifestyle: "Gossip washed in, washed out, came, went, moved on to the next target" (Burns, 2018: 5). The most harming gossip is that middle sister has an affair with the milkman, who is 
thought to be married. Alison Garden stresses that love intertwined with danger has been a common tradition since ancient Irish myths (Garden, 2018, October 15). In the novel, the tradition is maintained and represented with an alleged affair between the narrator and the milkman. Middle sister, unfortunately, cannot sustain an enduring, loving relationship, and refers to her boyfriend as maybeboyfriend. She tries to prevent malicious gossips about her, but even her mother does not believe her because men in paramilitary groups are thought to be targeted by women. They are thought to be heroes of their era: "In our district the renouncers-of-the-state were assumed the good guys, the heroes, the men of honour, the dauntless, legendary warriors, outnumbered, risking their lives" (Burns, 2018: 118). Women unlike the narrator actually want to have a relationship with these men because they are highly popular. To achieve their life-long dreams, women want to be seen with them: "He had to be leader, Number One, making her in turn Number One Attachment" (Burns, 2018: 121). It should be pointed out that women are considered to be mere attachments, and their values are closely dependant on their husbands'. The expectations of the community from women are mirrored in women's choices. Empowering women is unthinkable during the Troubles, and women, in order to be empowered, use these paramilitaries regardless of their illegal activities. The community is thus apparently effective and successful in forming similar women. The narrator, of course, is not one of them, which makes people react against her. Every woman is expected to be predictable. The narrator's unpredictable behaviours and wishes are beyond a doubt not permissible. According to the community, paramilitary groups are acting in line with a noble cause. Even the narrator's two brothers are in these violent groups. When the narrator denies the assumed affair with the milkman, people tend not to believe her because as a young girl, she is supposed to wish a marriage with one of these ostensibly brave men.

The narrator is accused because of "reading-while-walking". This innocent activity is presented as a proof of defiance against the government; however, it is her favourite activity to escape reality: "Every weekday, rain or shine, gunplay or bombs, stand-off or riots, I preferred to walk home reading my latest book" (Burns, 2018: 5). According to Drong, middle sister rejects the realities of her community and reads the novels of previous centuries to step out of the fixed boundaries determined by her nationalist community. The atmosphere in the Troubles is intrusive, and the narrator avoids any forms of infiltration. To that end, she reads novels from earlier centuries (Danacl, 2020). Anna Burns describes the period as threatening (Burns, 2020, May), and the narrator to escape this threatening atmosphere chooses to read English and French writers by discarding the territorial boundaries (Drong, 2020: 175). The narrator is free from any consequential loss dictated by the community. She is an intelligent, educated young woman who does not comply with her society. She is not possessed with all the ideological setbacks that two communities create. Instead, she finds comfort in especially the novels of the $19^{\text {th }}$ century; however, she is soon stigmatized.

From the perspective of comparative literature, it is vital to say that analysing two different literary works enhances our perception since being utterly original without being influenced by other literary works is nearly impossible (Aytaç, 1997, p. 14). Investigating two novels discussing similar experiences written in different countries can be illuminating since authors are able to reflect those incidents which affected a certain period of time in the past craftly. In this sense, both Burns and Tekin reflects highly similar themes although the happenings are entirely different. Comparative literature by studying intercultural relations uncovers their reflections in literary works (Kefeli, 2006). The need for comparison emerges from the fact that there are various parallels between two literary works despite having been written in different eras and geographies. It is acknowledged that comparative literature has a rich and intellectually accepted history (Tötösy de Zepetnek, 1999). This richness still needs to be studied extensively in literary works. 


\section{The Troubles in Northern Ireland and political violence in Turkey in the 1970s}

The setting of Milkman is 1970 s in Northern Ireland. It depicts traumatic times called the "Troubles". Two main groups clashing resulted in about 3600 deaths (Mesev, Downs, Binns, Courtney, \& Shirlow, 2008, p. 84) and a civil war that continued for decades. Moreover, it should be noted that a close connection exists between the death rate and "severe segregation" (Mesev et al., 2008: 97). In communities where radical people live, violence intensifies and the death rate increases. A similar radical community is portrayed in the novel. The violence turns into a vicious circle of revenge, and many lives are lost form both sides.

In an interview, Burns explains that the setting is not Belfast in 1970s but anywhere with a totalitarian regime: "I would like to think it could be seen as any sort of totalitarian, closed society existing in similarly oppressive conditions" (2018, October 17, para. 5). This is the reason for Burns's not including any proper names in her novel. Burns states that she will continue to write about Northern Ireland and the Troubles because the traumatic period changed the author's life and perspective considerably: “The Troubles is such an enormous, immense occurrence in my life, and in other people's lives, that it demands to be written about" (Burns, 2018, October 17, para. 8). Burns, in an interview, explains that in the country, during the Troubles, violence demonstrated itself among adults, children, and even dogs apart from paramilitary groups (Burns, 2018, November 29). The scene in which all the dogs have been piled up after being killed is actually the writer's real memory when she was seven or eight (Burns, 2018, October 24). The author's memory and fiction are intermingled to create a totalitarian and oppressive regime.

The Troubles affected the mental health of people and the areas they live in as well. It is stated that exposure to violence during the Troubles in childhood is an independent factor that causes DESNOS (Dorahy et al., 2009). These affected areas are largely consisted of Catholic people with lower incomes. According to the study, people from the working class are visibly more affected by the Troubles (O'Reilly \& Stevenson, 2003). In a study, it is concluded that attacks take place mainly in economically disadvantaged and severely segregated areas (Mesev et al., 2008, p. 100). The population in the novel is composed of deprived and underprivileged people, which is in accordance with the findings of the study above. Only in direction of a separate nation, can these people dream of a bright future. The narrator, however, stands out amongst other regardless of her economic status because she is above all the politically manipulated movements. Her difference from others gets more visible once the dynamics of the community are revealed. The sisters in the novel are forced to behave in certain rules, and they are manipulated by "neighbours", which is a quite effective tool because the power of gossip enhances the power of the group. The narrator thinks: "The very momentum of the invidious group mind was enough to sway and trick a person in" (Burns, 2018: 107). As it is clear, people are unable to rise above the group thinking whereas the narrator is individualistic and can be best described as a loner in her own thoughts. The milkman as an intruder violates her freedom to be away from the collectivism of the $20^{\text {th }}$ century in that society.

Catholic Irish Republicans urged the country to break free from the British rule and demanded autonomy while Protestant British Loyalists, defended that the country would thrive with the United Kingdom. This conflict, having at the same time denominational differences, could not be resolved, and it had devastating effects on the Northern Ireland. In a study, it is stated that some traumatic effects of the Troubles still exist in the adult population (Ferry et al., 2014). Republicans secured the commemorative narration as an oppressed group against the state (Graham \& Whelan, 2007). 
Investigating the political turmoil between 1968 and 1972, in Northern Ireland, three main acts of violence emerged. These acts stemmed from protests, sectarian tension, and armed conflagration (De Fazio, 2020). Robert W. White underlines the fact that to determine the extent of violence, the number of total deaths can be misleading because it "mixes violence by anti-state insurgents, pro-state vigilantes, and state forces themselves" (1993, p. 575). In another study, it is emphasized that intergroup contact has a key role in bringing the divided groups together (Hewstone, Cairns, Voci, Hamberger, \& Niens, 2006). A highly segregated society is thus depicted in the novel. The society is divided into two large groups: defenders of status quo and a minority group: “[W]e might make an effort and say 'defender' or 'renouncer', though only when attempting to enlighten outsiders, for mostly we didn't bother when it was only ourselves. 'Us' and 'them' was second nature" (Burns, 2018, p. 22). It is observable in the novel that two groups' unification to form one country is a far-fetched dream as they are separated from each other socially, religiously, but mainly politically. The narrator even gives examples of certain appropriate names that are acceptable in two groups. They avoid using the banned names to prevent themselves from being labelled (Burns, 2018, p. 23) because "[t]hese were knife-edge times, primal times, with everybody suspicious of everybody" (Burns, 2018, p. 27). Communal policing becomes a part of the daily life. People can easily report infringers to paramilitary groups, and they punish them according to their made-up laws. These groups are both judges and prosecutors: "There were beatings, brandings, tar and featherings, disappearances" (Burns, 2018, p. 119). It has been reported that women are tied to trees, tarred and feathered if they have relationships with soldiers (McDonald, 2009, November 27). Violence is prevalent in the Troubles, and the main reason the narrator does not report her stalkers is this accustomed lack of violence. In his study, White (1993, p. 583) concludes:

In Northern Ireland, anti-state insurgents, pro-state vigilante counterinsurgents, and the state are all caught in a complex web of violence. These groups have different motivations, and the dynamics of the conflict in Northern Ireland cannot be understood without examining the violence perpetrated by each group.

In such an atmosphere, middle sister is not interested in political acts of the era. She does not hold strong political opinions and mocks the factors generating the division wryly. One common feature of these groups is the fact that not resorting to violence to achieve peace is not considered to be a possibility. Peace talks do not remain on the agenda. People in paramilitary groups abuse the power that the group generates. The narrator's another stalker, Somebody McSomebody, who threatens to shoot the narrator in the opening lines of the novel, switches to the first-person plural all of a sudden while threatening her after she rejects his company (Burns, 2018, p. 3). These groups thus are reflected in the novel, not as groups of people united in an honourable and just cause, but as gangs enjoying brute force.

The narrator gets stuck between the public opinion and the possibility of a violent attack: "[A]nd public transport, because of bombscares and hijackings, was intermittently withdrawn" (Burns, 2018, p. 3). She avoids using public transportation because she likes walking and reading; however, gender oppression has visible effects even on daily activities. The narrator is seen with the milkman who offers her a ride, and a rumour spreads. The narrator's eldest sister comes to warn her with her husband's instruction. The eldest sister is clearly submissive and follows the rules enforced by the society: "I had just so much anger - at her, for being the wee wife, for doing always exactly what he told her to and at him" (Burns, 2018, p. 4). The clear contrast between the narrator and her sister causes tension, which also exists between the opposing groups in the country. The eldest sister cannot take action and leave her husband although she does not have feelings for him and is aware of his affairs. It is interesting to note that while the eldest sister is not pleased with her life, she cannot voice her thoughts. The eldest 
sister is oppressed by her husband but cannot complain because of the responsibilities and public opinions imposed on her.

Turkey had a similar but more intensive and threatening experience in the 1970s. In a retrospective analysis, it is stated that political violence that took place between 1976 and 1980 caused about 5000 deaths (Sayari, 2010). The elected government of Demirel, leader of the Justice Party (JP), was removed from the office, and the Chief of the General Staff General Kenan Evren overthrew the civilian government. There were fifty executions, and 600.000 people were detained. Ex-president of Turkey Kenan Evren in 2014 was given life sentence ("Turkey gives life sentences to surviving 1980 coup leaders," June 18, 2014). The events that led to the military coup were more violent and threatening. The leftist group called revolutionaries and the far-right group called idealists, who were considered to be mainly religious nationalists, clashed constantly for decades. The ideological rivalry between the left and right organizations led to street violence and terror. Due to the left-right street violence, the military intervened and handed the 1971 Turkish military memorandum, which was an ultimatum that demanded the government to take action against anarchy on streets. Turkey has suffered greatly from coups and coup attempts, one of which was carried out in 2016. It was proved that democracy would always stay fragile. It is pointed out that although leftist and rightist organizations were responsible for most of the terrorist attacks during 1976 and 1980, radical Kurdish separatist also joined in the attacks during 1979 and 1980 (Sayari, 2010, p. 203). Turkey in those years suffered tremendously from terrorist attacks from various sides.

It is clear that Turkey was surrounded by radical terror organizations with different radical agendas. People were engulfed in political violence carried out by different terrorist groups. Sayari highlights the vicious circle of killings during the period. The moment a member of a leftist or rightist terrorist group was killed, they were declared martyr, and the supporters gathered to bid farewell accordingly. This also led to a retaliation (Sayari, 2010, pp. 203-204). Michael M. Gunter, who analyses the period in detail, underlines the political instability in Turkey from 1971 to 1980, during which ten governments were in power (Gunter, 1989, p. 64). Gunter also stresses the threatening reality of terrorism and anarchy in the late 1970 (1989). In such a politically oriented atmosphere, especially university students had political ideas involuntarily. Politics surrounded the reality of the country.

\section{Oppression in hard times: Being a woman in the Troubles}

The narrator defines the society in this era as "hair-trigger" (Burns, 2018, p. 6). She cannot complain about the milkman's presence unless he physically abuses her. It turns out that to be able to complain about a person, the narrator has to be physically subjected to physical coercion: "Everything had to be physical, had to be intellectually reasonable in order to be comprehensible" (Burns, 2018, p. 64). Harassment comes in various forms; however, in such a community full of violence, abusing women verbally or invading their personal space does not count as a basis for complaint. In a study, it is expressed that one of the positive outcomes of the \#MeToo movement is the encouragement of women to reveal their perpetrators (Gupta, Gupta, \& Nehra, 2019). The novel is closely related to \#MeToo movement. Women reveal their abusers after they find courage as it can be challenging to admit being abused in the society. However, in an interview, Burns states that she completed the novel in 2014 before \#MeToo movement (Burns, 2018, October 24). This shows that Burns advocated women's rights before the movement earned a substantial place in the world. The movement is crucial in terms of revealing how common sexual harassment is in the world. Claire McKinney puts forward that by accepting the harassment, women both face the past and accept "the facticity of their bodies" (2019, p. 93). Starting 
from the film industry, women from different occupations supported the cause. In the novel, the milkman arranges the time to run with her and comes out of nowhere to run with the narrator. However, he cannot keep up with the narrator's pace and slows her running. She cannot object to that "because the conditioning of males and females here would never have allowed that. This was the 'I'm male and you're female' territory" (Burns, 2018, pp. 7-8). She is silenced because she clearly knows that reflecting her thoughts is a futile effort: "[H]ow could I open my mouth and threaten widespread disintegration of the current status quo?" (Burns, 2018, p. 64). Getting strength from status quo, the milkman makes bolder moves. He stalks the narrator, has information about her daily routine and work schedule. Furthermore, he stalks her maybe-boyfriend out of jealousy and threatens to kill him.

Women, apart from being required to be obedient, are demanded to complete varied tasks, the most important of which is marriage. An expectation from a young girl is to get married at the age of sixteen (Burns, 2018, October 24). The narrator's mother constantly urges her daughter to marry: "Since my sixteenth birthday two years earlier ma had tormented herself and me because I was not married" (Burns, 2018, p. 45). Her mother describes the narrator's bachelorhood as unsettling because she may be a disturbing example for younger girls. The narrator wishes to speak her mind and say: "[T]his is my life and I love you, or maybe I don't love you, but this is who I am, what I stand for and these are the lines, mother" (Burns, 2018, p. 57). Marriage is considered to be God's order. Neighbours repetitively warns the narrator of the consequences that being single brings with. She is asked to fit in the norms of their community, the rules of which are strict and rigid. Women are asked to complete their daily tasks and routines; marriage is the main component: "And what of your female destiny? The daily round? The common task?" (Burns, 2018, p. 50). In the community, marriage is regarded as the destiny for women. They are not expected to have education or jobs that contribute to the quality of their lives. The eldest sister's marriage is not a failure no matter how unhappy she is because "[m]arriage wasn't meant to be a bed of roses. It was a divine decree, a communal duty, a responsibility" (Burns, 2018, p. 50). The narrator's mother lists a series of instructions to honour husbands. According to the mother, a girl has to be married so that she can be morally intact: "Married. Registered. With reputation intact" (Burns, 2018, p. 123). The mother is highly stereotypical, not much expected from in terms of character development. Her fixated ideas on honour and marriage are the first steps to oppress her daughters. The community thus is considered to be entitled to take necessary steps to "discipline" those violating their tasks. While men are trapped among countless social, political, and religious rules to obey, women are given more responsibilities along with the rules men have to follow. The Troubles thus is depicted as an era where women are directed by fear and intimidation.

The narrator's second sister has been ostracized from the nationalist community because of her marriage to a state-forces person. It is necessary in the community to get married to someone from the right religion. She allegedly lives in England, which is called in the novel "over the water". In an inescapable community, the second sister finds the opportunity to leave the Troubles behind her, and she is assumed never to return. Because of her escape, she is considered to be a traitor among radical nationalists in the community as she gets married to a state defender and ignores the strict rules of the minority group. She will definitely not return to her community since she is aware of the consequences of her flee. She would be punished by the paramilitary group for defying the rule not to get married to a pro-government enemy. Studying the poems of Heaney and McGuckian, Walsh states that woman body is portrayed as a place for political violence, and that women are silenced. (Walsh, 2020). Walsh underlines that the Troubles emerged from several causes such as the partition of Ireland in 1921, British invasion, and ignoring the civil rights of Catholic nationalist community, a minority group in Northern Ireland (2020, p. 2). Silencing women is manifested in the second sister's flee to England to form a new life. Later, she 
is whipped by paramilitaries because of visiting her family. Even though England is not mentioned and described as the country "over the water", and it is discredited since the sisters' childhood, they do not take these slanders seriously. The narrator and her sisters are not politically oriented, and they show that they have free will. To give an example, three younger sisters one day come home with newspapers from "over there". Their elder sisters are nervous and worried as it is illegal to read the papers of the other side. They say: "We're busy. We're trying to understand their viewpoint”" (Burns, 2018, pp. 149150). Three younger sisters try to have an opinion about the loyalists' perspectives. They want to understand the reason why they live is such a highly divided society in the same country. This proves that these sisters will not yield to the demands of their community.

As much as women are hindered by gender inequality, men are demanded to behave in certain predetermined instructions. They are expected to be manly. The fact that maybe-boyfriend's best friend is a chef arises questions about him: "[H]e was a chef which meant homosexual with a drive to recruit male heterosexuals into the homosexual fold" (Burns, 2018, p. 32). In a community where the paramilitary renouncers form gang-like groups and terrorize the residents, gender stereotypes are polarized more than ever.

In the novel, there is a feminist organization formed by seven women. Another woman comes from downtown every two weeks to inform and inspire them. False accusations about this woman are made, and she is slandered because of not being a part of their community. In the community, even the word "feminism" is not tolerated (Burns, 2018, p. 152). These women get together and talk about ongoing sex discrimination for centuries and hang posters of inspirational women in history on the walls. The renouncers break into their house and threaten them. "Traditional women" as called in the novel, however, prevent any violent attacks on these women. This repugnant attack shows that even a small group of women are not entitled to talk about their problems. Undermining the authority of the community is a threat to the paramilitaries. There is also a witty comparison in the novel between "traditional" and "issue" women. Hundreds of traditional women (not interested in feminism) break the curfew imposed by the government together forming an alliance. In the novel, this is not reflected as an act of freedom because women after breaking the curfew attend to house chores. Traditional women do not want to be considered to be feminists on TV as their sole aim is to defeat the curfew. While the "issue women" are expected to talk about injustice through the centuries, they talk about women's daily problems such as sexual and verbal harassment, physical violence, and getting molested. Traditional women prevent paramilitaries from hurting these women by persuading them. It is interesting to note that women are not interested in hearing women's problems, and the small feminist organization comes to an end swiftly because they are not supported in the community, not even by other women.

Another key factor to remember about the narrator is that she is not politically invested in the struggles or the challenges of the period. She avoids the daily problems; however, says that she learns about them unconsciously: "I myself paid little attention to the problems, but I paid at least the minimum, something I could not have avoided because of osmosis" (Burns, 2018, p. 59). Although she is not interested in the political goals of the community, she cannot help but learn them unintentionally: "Of course, as regards living here, a person could not help but have a view" (Burns, 2018, p. 112). It should be noted that living in such a strict community does not grant the narrator the freedom to choose but violates her personal rights trying to manipulate and make her have the same ideological thoughts like others. Any kinds of contradictory behaviours are not tolerated. She states: "I couldn't stop having a view" (Burns, 2018, p. 112). The period infiltrates her thoughts. 
In the novel, a similarity is drawn between the narrator and cats. The narrator is identified with them: "They go their way, do their thing, are not subservient and will never apologize" (Burns, 2018, p. 93). During the time cats were considered to be "subversive" (Burns, 2018, p. 94), which reminds us of the narrator's subversive act of reading-while-walking. The narrator's personality is similar to cats described in the novel. Furthermore, there is a contrast built upon a dichotomy: obedience to authority and rebellion. On one side, there is the narrator with free will while on the other side, there are those relying on conformity for the sake of being socially accepted. These people are resembled to dogs: "Dogs were sturdy, loyal, feudal, good for man's account of himself with a slavish need to be obedient to someone" (Burns, 2018, p. 94). The contrast here shows that the narrator will never be able to fit in the society, and she does not want to be socially accepted and stripped off her rights and characteristics that shape who she is. She wishes to be acknowledged and heard without any outer factors and infiltrators. A change is inevitable but in a slow progress in a society where mutual understanding and empathy are desperately needed. Even a fierce feminist like the third brother-in-law may condemn the narrator's basic freedom and warns her of possible consequences. The community depicted in the novel is at war with empathy, and any slight changes have extreme responses. Women in a such a suffocating atmosphere need to be acknowledged firstly by their own families.

\section{Gece Dersleri: A politically manipulated young woman, Gülfidan}

Gece Dersleri, like Milkman, heavily depends on the narrator's distant memories. By remembering the past, she both feels guilty and nostalgic. These contradictory feelings create a dreamlike obscure setting where the reader is unable to follow a linear narrative. The author uses the stream of consciousness techniques throughout the novel; however, it is easier to follow. The narrator, once a fierce leftist, gives an account of her experiences probably not objectively. Tekin's novel starts with the acceptance of this truth as the narrator's reliability is questioned. The novel starts with "a young militant's faded memories" (Tekin, 2004, p. 1). The narrator, possibly with the intent of acquitting herself, narrates the events from her perspective. It is stressed that her memories are faded and not reliable. It raises two problems in narration. The first one is that remembering a past event is in need of being verified, and the second problem is that Gülfidan, to what extent, is willing to incriminate herself because of her actions against the state. From the first paragraph, the narrator's reliability rises questions like it does in Milkman because in the process of recounting the past, it is inevitable to lose objectivity.

Although it is fictional, the novel includes some historical information as the setting is Turkey in the 1970s, when the political mayhem embodied the whole country. The novel uses the format of epistolary (exchanging letters), and it does not follow a linear time order. Aside from politics, the novel deals with problems of women in the society where at the time empowering women is not welcomed by all. In 1930, women were granted suffrage to vote in regional elections, and they were given the right to elect and be elected, which was among the first in Europe. In 1934, they were granted suffrage in national elections (Cinar \& Kose, 2018, p. 365). Although the revolution that led to the foundation of Turkish Republic granted women vital public rights, the place of women in the society did not improve because of traditional limitations. The women's suffrage alone is not enough to evaluate women's rights in reality because many still continue to suffer from prejudices against them and the patriarchy. Turkey ranks $109^{\text {th }}$ among $15^{2}$ countries in the world in the gender gap index (World Economic Forum, 2019, p. 13). Empowering women politically is still a controversial subject despite being granted the right to vote in national elections in 1934. Considering the fact that women were more politically oriented in the 1970s, it is challenging to accept the reality that they were not granted the power to function in the society by themselves. Women were isolated: “I come from a house where women are lonely', I wailed" (Tekin, 
2004, p. 7). Gülfidan defies the notion to push women aside. Although women's empowerment is vital to form a better society (Cinar \& Kose, 2018), they are treated as second-class citizens. Gülfidan, as a part of an allegedly revolutionary act, is not respected by women because of her relationship with the head of the organization. This binary position leads to confusion and isolation.

Emin Alper stresses that the number of social protests increased dramatically varying from students' uprisings to peasants' protesting prices between the years 1968-1971 in Turkey. The protests included people from various professionals and from every layer of the society (Alper, 2010). The circle of protests clearly affected people from every profession, especially students. In Gece Dersleri, the wave of protests is portrayed by Gülfidan's accounts. Her past consists of placards, anti-government protests, anarchy, and anthems. It was clearly a new era for Turkey because it was unparalleled with countless protests and strikes on streets. Alper presents a very important perspective by stating that nonfictional narratives written by the activists of the era are solely tributes to their allegedly noble fights (Alper, 2010). It should be fair to conclude that Gülfidan's narration of the events is not entirely based on facts, but rather exaggerations. The ode to her past for that reason is not reliable. Sibel Irzlk states that these narratives do not reflect the cultural memory because they tend to be melancholic: "The coup narratives of the 1980 s as well as those belonging to what might be called a boom from the mid-199os to today are distinctly melancholic texts that reflect these limitations of cultural memory" (Irzık, 2014, p. 47). Exaltation and melancholy emerge resulting in unreliable narratives. Although Gülfidan is ashamed of her actions during the "Troubles" of Turkey, it is not likely to deduce how sincere she is. Another key detail to remember is that students after the May 27 coup in 1960 were flattered as heroes by the military as they used the students' protests as an excuse to take action (Alper, 2010, p. 81). As the political crisis intensified, the military seized the power nearly every decade from 1960 to 1980 . Irzik highlights: "The 1971 and 1980 coups were both ostensibly triggered by a political crisis in which the violent struggle between the militant right and the revolutionary left had peaked" (Irzlk, 2014, p. 47). Two groups imposed various responsibilities on their followers. Gülfidan, as an eighteen-year-old young girl, clearly is influenced by these exaltations, being considered to have saved the country. She is aware of the fact that students once created a big change in the country, and that they can achieve it one more time. She cannot grasp the idea that they are being manipulated and used. She as a mature woman understands her mistakes in the past. Compared to the middle sister in Milkman, Gülfidan is naïve, unable to form her true self, and easily manipulated. While the middle sister has political opinions only involuntarily because of her brothers' involvement.

The narrator prepares political placards and slogans (Tekin, 2004, p. 3). Her existence revolves around politics. Gülfidan (aka Secretary Wind) wavers between her identity and her political identity assigned to her without being asked. She does not even understand the reason for her alias. In a politically separated community, she has to finalize her role in the leftist group; however, it is not easy to lead a double life: "I find it hard to remember my name and who I am" (Tekin, 2004, p. 9). It is fair to conclude that she is mostly known with her alliance, which means that political dissidence covers the majority of her life. She does not have time to construct Gülfidan's personality in her daily life. She is clearly away from her desires, hopes, and personal problems. Leading a life in political protests and fighting a war against right-wingers, whom she considers to be reactionary and conservative. She aims to remove the uneven development and inequality in the society by organizing protests on streets. She believes in her cause; however, in the course of time, forgetting her real self makes her feel woeful: "The vision of my life fading turned away from my memory of our people" (Tekin, 2004, p. 9). It should be noted that she identifies herself with her people; nevertheless, she is aware of the fact that she does not live her life 
fully. This fact, elapsing time, is in contrast with her allegedly high cause. The need to be a part of something greater than her gives meaning to her life even though it does not last.

Gülfidan is connected to the women's branch of the leftist organization. She refers to them as "pioneer women guards with red wings" (Tekin, 2004, p. 10). They give her the task to work in a factory, but she refuses: "Being a worker does not equal to my dreams" (Tekin, 2004, p. 10). The moment she rejects the task, she is condemned and accused of treason. The contrast between Gülfidan's respect to the branch and their condescending reply show that the group comes into prominence and dominates the individual. The branch refers to Gülfidan as "the storyteller of illegality" (Tekin, 2004, p. 11). She is not worth much compared to the benefit of the majority. The leftist ideology thus is criticized through the women's branch because while they, on the surface, defend human rights, they do not hesitate to crush individuals. Gülfidan is a dreamer like the middle sister in Milkman. She does not wish to work in a factory because her dreams are bigger. Gülfidan apparently has a relationship with the head of the organization, and women condemn this relationship: "[Y]ou persuaded him to organize the boys. You caused us much trouble" (Tekin, 2004, p. 11). Gülfidan is assumed to manipulate the head of the organization with her femininity. The female body is represented as an object of desire, and Gülfidan's intellectual integrity is overseen by women. It is problematic and concerning to encounter women's prejudices against women. The moment Gülfidan starts a relationship with the man in charge, she is considered solely to be a product of authority. Furthermore, Clara Zetkin, women's rightist and defender of Marxism-Leninism, is mentioned in novel. She is evidently taken as an example among women; however, individuals are scrutinized, and they are expected to fit in a predetermined mould. Gülfidan writes: "Then I understood that I would disappear shrinking bit by bit in my fixed mould under the code name Secretary Wind and cried in fear" (Tekin, 2004, p. 15). She desperately struggles to come to terms with her past. The only person she misses to be with is Mukoshka, her confidant and sister. She is the only person worth remembering in her past. Her revolutionist dreams are no longer with her because she is aware of the fact that the severe artificial division between the leftist and rightist groups turned Turkey into a war zone. It caused great distress and loss of hope in the country. While people were struggling to live under harsh economic problems, they at the same time struggled to survive the political chaos and anarchy on streets. They were labelled; what is more, the streets were shared and owned. The political atmosphere in the novel is so suffocating that individuals cannot create their identities but rather rely on others' perceptions. Manipulation and community pressure are two main components of the society in the 1970s. Gülfidan as a young woman was a part of this turmoil, and she clearly had a hard time accepting this reality. She was the part of a destructive problem in the country, and that is the reason why she is ashamed of her past now.

In the novel, the Persian mythological creature Div-e Sepid (White Demon) is also mentioned (Tekin, 2004, p. 20). The narrator feels trapped in Div-e Sepid's dungeon. He was killed by Rustam as he killed many traders and travellers (Nardo, 2012, p. 60). As the creature has great strength, the narrator cannot defeat the male dominance she feels constantly. The Persian myth is used as a symbol to show the narrator's feeling of weakness and entrapment. The narrator, Gülfidan's way of dressing is depicted as a bohemian style. She wears old jeans and an outworn black pullover (Tekin, 2004, p. 21) to demonstrate that she does not want to be associated with her femininity. Her cause and revolutionary thoughts define the narrator, and as a young woman and student empowered by the military in 1960, she wants to be defined by these traits, not by her relationship with a man. In this paragraph, she mentions Div-e Sepid one more time to emphasize his gender. She specifically indicates his maleness because she is aware that gender discrimination is exorbitant in the country like Northern Ireland during the 1970s. 
She feels nostalgic and misses her mother. There are a few things to miss for her in her past, and her mother is one of them. Her mother's expectations and the reality do not comply. Furthermore, Gülfidan is regretful to become a destructive militia and an anarchic: "and I turned into a militia like the wind" (Tekin, 2004, p. 33). Although her actions as a militia were favoured by her peers at the time of social protests, they were criticized and condemned later. The blood feud threatened the country's future. The young generation's potential to turn Turkey into a modern and developed country was wasted because of an intangible division created and manufactured by external forces and factors. Gülfidan now is aware of this fact that she wasted her life in vain chasing political purposes.

In her letter to Mukoshka, Gülfidan is revealed to have changed her ideas about politics: "All the houses are dirty, what does it mean? You mean that we are classless. Let go of these emotional theories, tell me candidly" (Tekin, 2004, p. 38). The feud raging between Gülfidan's old and new self reveals the contrast between the past and the present. The narrator does not hold the socialist ideology. She does not believe in the existence of a classless society and dismisses it since the leftist ideas now seem emotional and unreal. It is worth noting that Secretary Wind's existence is now questionable, and Gülfidan seizes the control of her identity. She no longer has strong political and social views. In the 1970 s until the military coup in 1980, violence resulting in blood revenge surrounded Turkey. The mutual hatred stemming from religious and political intolerance turned people like Gülfidan into completely altered personalities. Gülfidan is now aware of her faults in the past and regrets deep down inside. On the other hand, the narrator in Milkman reaches her self-actualization before Gülfidan does. She does not want to be a part of the Troubles. The middle sister and Gülfidan have eventually the same perspective for life. However, Gülfidan sees it retrospectively.

At the age of eighteen, Gülfidan as Secretary Wind cannot hold on to her life because she is manipulated and directed in line with the demands of the organization. She cannot possess her life: "OOh my life, you have never been mine...”' (Tekin, 2004, p. 47). Her life has always been others' because an individual owns a political view unconsciously in such a divided environment. Belonging to a group of people offers a sense of security, and people by constantly talking about politics in fact politicize those apolitical. The dichotomy in the society pervades all, and Gülfidan is the true representation of it because there are two of them: Gülfidan and Secretary Wind. Even if an individual does not wish to participate in the political vendetta, like the middle sister in Milkman, they are instantly surrounded and asked to have a political view to save the country; otherwise, she is seen as a threat to the country's entirety. Gülfidan by reaching her self-actualization now despises this perspective and feels guilty. The past for the narrator consists of Mukoshka and her mother. The rest is guilt and not worth recalling.

The leftists desire for a revolution in fair distribution of income, government, and labour rights. Gülfidan finds out that she is pregnant; nevertheless, the organization wants her to have her baby aborted since she has more important tasks such as decorating the congress hall (Tekin, 2004, p. 73). The individual is clearly oppressed by the majority, who defines themselves as activists of human rights and defenders of the proletariat. Gülfidan now wants to set herself free from the oppression. She shares her thoughts with her confidant: "It is raining, my dear. You Mukoshka, look after our class, open an umbrella for the poor, who have caused trouble to the world..." (Tekin, 2004, p. 150). Although she defends the working class in this excerpt, she is in obvious dilemma: "Come, let those poor people get soaked, never mind Mukoshka... We have already skipped the steps and left the debris behind us... Count to see how many years we are ahead of them..." (Tekin, 2004, p. 150). As it is evident from the excerpt, Gülfidan now thinks that defending a class is a futile effort, and looking after her future is a vital step towards accepting the reality. The idea of a class unity is just a dream: "Maybe the thing we call class is the act of 
legitimatizing our wounds" (Tekin, 2004, p. 150). In the political turmoil of the 1970s, the leftists and rightists went through inexplicable pain. Both sides suffered tremendously leaving behind a country that needed much time to heal. Gülfidan thinks that the reality of suffering led to the idea of a class. She despises the idea of a class now.

\section{Conclusion}

Northern Ireland went through traumatic times for three decades, and thousands of people lost their lives because of political and religious differences that intensified in the 1970s. The traumatic effects of the Troubles still continue as it left deep scars in the history of Northern Ireland. With the Belfast Agreement in 1998, the Northern Ireland conflict ended with numerous effects. Milkman revisits this politically violent period with nameless characters without mentioning even the secs. The narrator in the novel does not fit in the community because of her unusual and unacceptable activities such as reading-while-walking or her indifference to marriage. The sisters are oppressed, and their rights are taken away. Being a woman in the Troubles requires obedience to authority. Paramilitary groups make it their duty to shape the community and make them comply with their unreal rules. The group power encourages communal policing, and people become suspicious of each other. In such a traumatic atmosphere, free-spirited women struggle to have their voices heard. The Troubles is thus a troublesome period especially for women as they cannot act violently or join in paramilitary groups. The period urges people to reach their common goal by force, and women are not suitable for such a violent act. Gülfidan, on the other hand, is substantially different from the narrator of Milkman because she was an active member of a leftist groups that organized countless protests on streets. In the 1970s, Turkey went through difficult times surrounded by violence perpetuated by every layer of the society. Workers went on strike; students occupied campuses. Gülfidan with the alias Secretary Wind as a young woman took part in organizing these protests. However, her old self revisits this era with guilt and shame. As a mature woman now, Gülfidan leaves her political identity and finds her true self. Latife Tekin presents a character that is in conflict with her old self. Gülfidan is ashamed of her past because she feels responsible for making a destructive effect on the future of Turkey. She understands now that they were manipulated in the past.

\section{References}

Alper, E. (2010). Reconsidering Social Movements in Turkey: The case of the 1968-71 Protest Cycle. New Perspectives on Turkey, 43, 63-96. doi:10.1017/So89663460000577X

Aytaç, G. (1997). Karşılaştırmah Edebiyat Bilimi. Ankara: Gündoğan Yayınları.

Burns, A. (2018). Milkman. The UK, London: Faber \& Faber.

Burns, A. (2018, November 29). The New Booker Prize Winner Who May Never Write Again/Interviewer: A. Marshall. The New York Times.

Burns, A. (2018, October 17). 'It's nice to feel I'm solvent. That's a huge gift': Anna Burns on her lifechanging Booker win/Interviewer: L. Allardice. The Guardian.

Burns, A. (2018, October 24). A history of violence: An interview with the 2018 man booker prize winner, anna burns/Interviewer: T. Gatti. New Statesman.

Burns, A. (2020, May). Anna Burns in conversation with Sheila McWade/Interviewer: S. McWade. Queen's University Belfast.

Çınar, K. \& Köse, T. (2018). The Determinants of Women's Empowerment in Turkey: A Multilevel Analysis. South European Society and Politics, 23(3), 365-386. doi:10.1080/13608746.2018.1511077 
Danacı, F. S. (2020). Surviving the Oppression in the Time of the Troubles: Anna Burns's Milkman. Litera, 30(2), 289-305. doi:10.26650/LITERA2020-0065

De Fazio, G. (2020). Unpacking Violent Contention: The Troubles in Northern Ireland, 1968-1972. Terrorism and Political Violence, 32(8), 1691-1711. doi:10.1080/09546553.2018.1500366

Dorahy, M. J. et al. (2009). Complex PTSD, Interpersonal Trauma and Relational Consequences: Findings from a Treatment-receiving Northern Irish Sample. Journal of Affective Disorders, 112(1-3), 71-80. doi:10.1016/j.jad.2008.04.003

Drong, L. (2020). Remembering a Transcultural Past: Recent Post-Tribal Fictions of Seventies Ardoyne. Critique: Studies in Contemporary Fiction, 61(2), 171-180. doi:10.1080/00111619.2019.1687416

Ferry, F. et al. (2014). Traumatic events and their relative PTSD burden in Northern Ireland: a consideration of the impact of the 'Troubles'. Social Psychiatry and Psychiatric Epidemiology, 49(3), 435-446. doi:10.1007/s00127-013-0757-0

Garden, A. (2018, October 15). In praise of 'Milkman', Ireland's Man Booker Prize winner. The Irish Times. Retrieved from https://www.irishtimes.com/culture/books/in-praise-of-milkmanireland-s-man-booker-prize-winner-1.3661398

Graham, B. \& Whelan, Y. (2007). The Legacies of the Dead: Commemorating the Troubles in Northern Ireland. Environment and Planning D-Society \& Space, 25(3), 476-495. doi:10.1068/d70j

Gunter, M. M. (1989). Political Instability in Turkey during the 1970s. Journal of Conflict Studies, 9(1).

Gupta, R. et al. (2019). Going Forward with \#MeToo Movement: Towards a Safer Work Environment. Journal of Psychosexual Health, 1(2), 174-179. doi:10.1177/2631831819862087

Hewstone, M. et al. (2006). Intergroup Contact, Forgiveness, and Experience of "The Troubles" in Northern Ireland. Journal of social issues, 62(1), 99-120. doi:10.1111/j.1540-4560.2006.00441.x

Irzık, S. (2014). Textualized Memories of Politics: Turkish Coup d’État Novels. In N. Segal \& D. Koleva (Eds.), From Literature to Cultural Literacy (pp. 43-61): Palgrave Macmillan UK.

Kefeli, E. (2006). Karşılaştırmalı Edebiyat: Tanım, Yöntem ve İncelemeler. Türkiye Araştırmaları Literatür Dergisi, (8), 331-350. Retrieved from https://dergipark.org.tr/tr/pub/talid/issue/43477/530624

McDonald, R. (2009, November 27). Has Northern Ireland left the past behind? BBC News. Retrieved from http://news.bbc.co.uk/2/hi/uk_news/northern_ireland/8381652.stm

McKinney, C. (2019). Sexual Coercion, Gender Construction, and Responsibility for Freedom: A Beauvoirian Account of Me Too. Journal of Women Politics \& Policy, 40(1), 75-96. doi:10.1080/1554477x.2019.1563415

Mesev, V. (2008). Measuring and Mapping Conflict-Related Deaths and Segregation: Lessons from the Belfast 'Troubles'. In D. Z. Sui (Ed.), Geospatial Technologies and Homeland Security: Research Frontiers and Future Challenges (pp. 83-101). Dordrecht: Springer Netherlands.

Nardo, D. (2012). Persian Mythology: Lucent Books.

O'Reilly, D. \& Stevenson, M. (2003). Mental Health in Northern Ireland: Have "the Troubles" Made It Worse?. Journal of Epidemiology and Community Health, 57(7), 488. doi:10.1136/jech.57.7.488

Sayari, S. (2010). Political Violence and Terrorism in Turkey, 1976-80: A Retrospective Analysis. Terrorism and Political Violence, 22(2), 198-215. doi:10.1080/09546550903574438

Tekin, L. (2004). Gece Dersleri (7th ed.). Istanbul: Everest Yayınları.

Tötösy de Zepetnek, S. (1999). From Comparative Literature Today Toward Comparative Cultural Studies. CLCWeb: Comparative Literature and Culture. 1.3. https://doi.org/10.7771/14814374.1041

Turkey gives life sentences to surviving 1980 coup leaders. (June 18, 2014). BBC. Retrieved from https://www.bbc.com/news/world-europe-27913560 
1044 / RumeliDE Journal of Language and Literature Studies 2021.25 (December)

The anatomy of two politically divided nations in the 1970s: Northern Ireland in Milkman and Turkey in Gece Dersleri / A. Tulgar (pp. 1030-1044)

Walsh, A. (2020). 'Curiosity with corpses': Poetry, nationalism and gender in Seamus Heaney's North (1975) and Medbh McGuckian's The Flower Master (1982). Journal of Gender Studies, 1-12. doi:10.1080/09589236.2020.1848534

White, R. W. (1993). On Measuring Political Violence: Northern Ireland, 1969 to 1980. American Sociological Review, 575-585.

World Economic Forum. (2019). Global Gender Gap Report 2020. Retrieved from http://www3.weforum.org/docs/WEF_GGGR_2020.pdf 